\title{
Haematological Profile of Broiler Chickens under Acute Stress Due to Shackling
}

\author{
I. BEDÁŇOVÁ, E. VOSLÁŘOVÁ, V. VEČEREK, V. PIŠTĚKOVÁ, P. CHLOUPEK \\ Department of Public Veterinary Medicine and Toxicology \\ University of Veterinary and Pharmaceutical Sciences Brno, Czech Republic
}

Received September 19, 2006

Accepted November 29, 2006

\begin{abstract}
Bedáňová I., E. Voslářová, V. Večerek, V. Pištěková, P. Chloupek: Haematological Profile of Broiler Chickens under Acute Stress Due to Shackling. Acta Vet. Brno 2007, 76: 129-135.

The aim of our experiment was to assess the stress response of broilers to different periods of shackling when conditions similar to practice at slaughterhouses were simulated. In this study, heterophil to lymphocyte $(\mathrm{H} / \mathrm{L})$ ratios were used as an index of stress status. Also total erythrocyte and leukocyte counts, haematocrit, haemoglobin, mean cell volume (MCV), mean cell haemoglobin $(\mathrm{MCH})$ and mean cell haemoglobin concentration $(\mathrm{MCHC})$ values were monitored and differential leukocyte count was assessed. At 42 days of age, 10 broilers were subjected to a 2-min shackling period (S2 group) and other 10 broilers were subjected to a 5-min shackling period (S5 group). Broilers were suspended from shackles placed in an experimental processing line and other stress factors (e.g. preslaughter transport, crating and ambient disturbances) were eliminated in order to assess the stress response to shackling particularly. When compared with an unshackled control, both S2 and S5 groups exhibited a highly significant increase in heterophil counts and $\mathrm{H} / \mathrm{L}$ ratio $20 \mathrm{~h}$ following shackling. When compared, the mean value of the $\mathrm{H} / \mathrm{L}$ ratio of S2 and S5 chickens was higher due to the longer shackling period. The difference, however, was not statistically significant. In addition, S5 broilers exhibited a statistically significant elevation in the number of basophils in comparison with the control. When compared with the control, S2 broilers exhibited a significant decrease in haemoglobin level, a highly significant decrease in erythrocyte cell count and MCHC values due to shackling. Both S2 and S5 groups of broilers manifested a highly significant increase in MCV values and markedly depressed erythrocyte count and MCHC values in comparison with unshackled broilers. When S2 and S5 broilers were compared, none of the monitored haematological indices of the erythrocyte count manifested any significant changes due to the different periods of shackling. Results of our experiment proved that the preslaughter shackling induced considerable changes in haematological indices of both leukocyte and erythrocyte count in broilers and indicated a markedly increased level of stress effects. In conclusion, using a method that eliminates the stress associated with the shackling of live birds before electrical stunning should be considered as a better option as far as bird welfare is concerned.
\end{abstract}

Haematology, poultry, stress, welfare

Nowadays, all animal husbandry sectors must react to increasing demands to ensure animal welfare (e.g. Dousek et al. 2002; Večerek et al. 2002, 2006; Busch 2005; Fulponi 2006; V oslářová et al. 2006). Furthermore, relationship between preslaughter stress and meat quality has already been proved (e.g. Mengert and Fehlhaber 1996; Debut et al. 2003). Several studies have attempted to determine which stage of the preslaughter processes is the most traumatic event for the birds. From their experimental study, Knowles and Broom (1990) concluded that the handling component was the most potent stressor for broiler chickens. The handling method adopted may have implications for bird welfare. Lately, the need for attenuating the adverse physiological and behavioural consequences associated with harvesting of broiler chickens is recognized within the poultry industry (Zulkifli et al. 2000).

The slaughter of poultry differs from the slaughter of all other meat-producing animals because the live birds are hung upside down in shackles prior to slaughter. Council Directive 
93/119/EC on the protection of animals at the time of slaughter or killing, sets an exception from the ban of suspending animals before stunning or killing. It states that the bird or rabbit may be suspended for slaughter provided that appropriate measures are taken to ensure that, on the point of being stunned, they are in a sufficiently relaxed state for stunning to be carried out effectively and without undue delay. Although this practice is necessary for present methods of humane slaughter, Sparrey and Kettlewell (1994) state that it causes possible distress and pain to the birds. Their study reviews the regulations on the provision for the welfare of poultry at slaughter as it affects shackling, the equipment involved in shackling, and the physiological and psychological effect of shackling on birds. Similarly, Raj and Tserveni-Gousi (2000) noted that electrical water bath stunning of broiler chickens shackled on a moving line is the most common method used to stun poultry under commercial conditions. However, as far as bird welfare is concerned, using a method eliminating the stress associated with the shackling of live birds before electrical stunning (e.g. stunning/killing of poultry still in their transport containers using gas mixtures) would appear to be the best future option. Kannan et al. (1997) studied the welfare and meat quality effects of shackling. They suggested a maximum time lapse of 2 min between shackling and stunning or killing to minimise stress and changes in the meat quality.

According to Gentle and Tilst on (2000), shackling of commercial poultry involves the insertion of each leg into parallel metal slots and holding the bird inverted for a period of time before stunning and slaughter. Based on monitoring nociceptors in the legs of poultry in response to quantitative mechanical stimulation, they concluded that shackling is likely to be a very painful procedure. Also vigorous struggling and wing flapping responses often shown by shackled chickens can compromise their welfare and seriously damage product quality (Jones et al. 1998a,b; S atterlee et al. 2000; Debut et al. 2003). Birds are not only shackled during the pre-slaughter processing, farmers or veterinarians often suspend growing broilers and laying hens by the legs for examination (Jones and Satterlee 1997).

The aim of our experiment was to evaluate stress response of broilers to different periods of shackling when conditions similar to practice at slaughterhouses were simulated. In this study, heterophil to lymphocyte $(\mathrm{H} / \mathrm{L})$ ratios were used as an index of stress status. The reliability of $\mathrm{H} / \mathrm{L}$ ratio as a biological index of stress in avian species has been comprehensively reviewed (Maxwell 1993). Furthermore, changes in other haematological parameters of red and white blood cell count caused by shackling of broilers were monitored. Gross and Siegel (1983) state that the number of heterophil cells per unit of blood increases and the number of lymphocytes decreases in birds under stress but the ratio of these cell types is less variable and thus a better measure than individual cell numbers. A normal ratio is about 0.4 but this can rise to 8 in birds under severe stress. According to Jensen et al. (2000), basophil numbers can also be increased during stress and this elevation can be more rapid than an increase in $\mathrm{H} / \mathrm{L}$ ratio. Authors have associated this with an acute stress of life-threatening magnitude.

Siegel and Gross (2000) state that under extended periods of higher levels of stress $\mathrm{H} / \mathrm{L}$ ratios ranged between 0.6 and 1.2 . A $\mathrm{H} / \mathrm{L}$ ratio above 1.3 usually indicates a disease in progress. Unusually low levels of environmental stimuli are characterized by $\mathrm{H} / \mathrm{L}$ ratios between 0.2 and 0.3 , demonstrating the need for some stress (stimulation) in order to maintain more efficient biochemical activity.

Gross (1990) reports that exposure to a short-term physical stressor resulted in changes in blood profiles such as fluctuation in $\mathrm{H} / \mathrm{L}$ ratios within $18 \mathrm{~h}$. The response peaked at about $20 \mathrm{~h}$ and returned to normal at about $30 \mathrm{~h}$.

A study which focused on monitoring the effects of different handling methods on stress reactions in blood of broilers was published by Zulkifli et al. (2000). In their experiment, the birds were subsequently subjected to either upright handling (one bird was held close to 
the experimenter's body in an upright position and stroked gently) or inverted handling (one bird was held by both legs in one hand in an inverted position and allowed to flap freely) for about $45 \mathrm{~s}$. Irrespective of the method used, subjecting chicks to a brief handling procedure resulted in an increase of elevated $\mathrm{H} / \mathrm{L}$ ratios for up to $20 \mathrm{~h}$, indicating a stress response.

\section{Materials and Methods}

Animals and their treatment

Stress effects of shackling on haematological indices of erythrocyte and leukocyte count of meat hybrid poultry breeds were monitored in a group of male ROSS 308 broilers (total number 200) aged 42 days. From the first day after hatching, broilers were housed on deep litter in an experimental barn with controlled light, heating, hygienic and feeding patterns according to standard breeding requirements for meat hybrid poultry. The ambient barn temperature was gradually decreased from $30 \pm 1^{\circ} \mathrm{C}$ on Day 1 to $20 \pm 1^{\circ} \mathrm{C}$ on the last day of fattening (Day 42 ). Depending on temperatures, relative humidity levels ranged between $20 \%$ and $60 \%$. When the broilers were 42 days old, 20 chickens were selected at random for tests. Five experimenters individually captured one broiler each, and transported it by-hand to the next-door test room, where chickens were immediately inverted and simultaneously suspended from stationary shackles placed in a line. The shackled broilers therefore could see, hear and partially touch each other during the test and were allowed to flap freely. 10 of the 20 broilers were subjected to a 2-min shackling period (S2 group) and the other 10 broilers were subjected to a 5-min shackling period (S5 group). The aim of the study was to assess the stress response of broilers to shackling particularly; therefore other stress factors (e.g. preslaughter transport, crating and ambient disturbances) were eliminated. After the test the 20 broilers were released, marked with paint and left undisturbed free in the barn. After 20 hours blood samples were withdrawn from the vena basilica in broilers of both test groups and also in the other 10 randomly selected broilers that were kept undisturbed for the whole preceeding period (control group - CON). For haematological examinations, the samples were stabilized by heparin. Blood samples were obtained after 20 hours because the $\mathrm{H} / \mathrm{L}$ ratio response to short-duration stress peaks after $20 \mathrm{~h}$ (Gross 1990; Zulkifli et al. 2002).

Haematological examinations

Examinations consisted of determining total erythrocyte and leukocyte counts, haematocrit values, haemoglobin levels and differential leukocyte counts, whereby the proportions of neutrophil, basophil and eosinophil granulocytes, lymphocytes and monocytes of the total leukocytes were computed. The total erythrocyte and leukocyte counts were determined by means of the flask method of dilution and counting corpuscles using the Bürker chamber. Haemoglobin levels were determined photometrically using the SPECOL-11 photometer and Drabkin's solution at the $540 \mathrm{~nm}$ wavelength, and haematocrit values were determined by means of the microhaematocrit technique according to Janetzki. Proportions of individual leukocyte types (in 200 cells) were computed from blood smears panoptically stained according to Pappenheim, with the use of a microscope with an immersion lens. MCV (mean cell value), MCH (mean cell haemoglobin) and MCHC (mean cell haemoglobin concentration) were also calculated.

\section{Statistical evaluation}

Results were analysed using the statistical package Unistat 5.1. Data were subjected to a one-way ANOVA and subsequently to the Bonferroni test to perform multiple comparisons in order to assess statistical significance of differences between all possible pairs of groups.

\section{Results}

Results of haematological examinations of broiler chickens stressed due to shackling for 2 minutes, for 5 minutes and unstressed broilers are given in Table 1 .

As follows from results, when compared with control, S2 broilers exhibited significant decrease in haemoglobin level $(p<0.05)$, and a highly significant decrease in erythrocyte count $(p<0.01)$ and MCHC values $(p<0.01)$ due to shackling. Both S2 and S5 groups of broilers manifested a highly significant increase in MCV values $(p<0.01)$ in comparison with unshackled broilers. Similarly to the S2 group, 5 minutes of shackling markedly depressed the erythrocyte count $(p<0.01)$ and MCHC values $(p<0.05)$ in broilers of the S5 group. When S2 and S5 broilers were compared, the monitored haematological indices of erythrocyte cell counts did not manifest any significant changes due to different time periods of shackling.

Results of examination of changes in differential leukocyte counts in the blood of broiler chickens stressed due to shackling for 2 minutes, for 5 minutes and unstressed broilers are given in Table 2. 
Table 1. Haematological parameters of broilers stressed due to shackling for $2 \mathrm{~min}$ ( $\mathrm{S} 2, \mathrm{n}=10$ ), for $5 \mathrm{~min}$ (S5, $\mathrm{n}=10)$ and unstressed broilers $(\mathrm{CON}, \mathrm{n}=10)$ : Means \pm SEM (Standard Error of Mean) and significance of multiple comparisons tests

\begin{tabular}{|l|c|c|c|}
\hline Parameter & CON & S2 & \multicolumn{1}{c|}{ S5 } \\
\hline $\begin{array}{l}\text { Haemoglobin } \\
(\mathrm{g} / \mathrm{l})\end{array}$ & $128.78^{\mathrm{b}} \pm 7.68$ & $100.60^{\mathrm{a}, \mathrm{c}} \pm 4.88$ & $116.83^{\mathrm{b}, \mathrm{c}} \pm 7.34$ \\
\hline $\begin{array}{l}\text { Haematocrit } \\
(1 / 1)\end{array}$ & $0.26^{\mathrm{a}} \pm 0.01$ & $0.27^{\mathrm{a}} \pm 0.01$ & $0.25^{\mathrm{a}} \pm 0.01$ \\
\hline $\begin{array}{l}\text { Erythrocytes } \\
(\mathrm{T} / 1)\end{array}$ & $3.38^{\mathrm{B}} \pm 0.17$ & $2.35^{\mathrm{a}} \pm 0.12$ & $2.34^{\mathrm{a}} \pm 0.19$ \\
\hline $\begin{array}{l}\mathrm{MCV} \\
(\mathrm{fl})\end{array}$ & $71.44^{\mathrm{a}} \pm 10.24$ & $115.63^{\mathrm{B}} \pm 5.53$ & $111.31^{\mathrm{B}} \pm 7.61$ \\
\hline $\begin{array}{l}\mathrm{MCH} \\
(\mathrm{pg})\end{array}$ & $39.52^{\mathrm{a}} \pm 4.13$ & $43.45^{\mathrm{a}} \pm 2.35$ & $51.56^{\mathrm{a}} \pm 3.89$ \\
\hline $\begin{array}{l}\mathrm{MCHC} \\
(\%)\end{array}$ & $50.76^{\mathrm{B}} \pm 2.61$ & $37.78^{\mathrm{a}} \pm 1.74$ & $46.97^{\mathrm{A}} \pm 2.87$ \\
\hline
\end{tabular}

$\mathrm{T} / 1=10^{12} / 1$

$\mathrm{MCV}=$ mean cell volume, $\mathrm{MCH}=$ mean cell haemoglobin, $\mathrm{MCHC}=$ mean cell haemoglobin concentration Means within a row lacking a common superscript differ. Identical letter size indicates $p<0.05$,

different letter size indicates $p<0.01$.

Table 2. Differential leukocyte counts of broilers stressed due to shackling for $2 \mathrm{~min}(\mathrm{~S} 2, \mathrm{n}=10)$, for $5 \mathrm{~min}$ $(\mathrm{S} 5, \mathrm{n}=10)$ and unstressed broilers $(\mathrm{CON}, \mathrm{n}=10)$ : Means \pm SEM (Standard Error of Mean) and significance of multiple comparisons tests

\begin{tabular}{|l|c|c|c|}
\hline Parameter & CON & S2 & S5 \\
\hline $\begin{array}{l}\text { Leukocytes } \\
(\mathrm{G} / \mathrm{l})\end{array}$ & $11.50^{\mathrm{a}} \pm 1.60$ & $17.90^{\mathrm{a}} \pm 1.08$ & $15.70^{\mathrm{a}} \pm 1.54$ \\
\hline $\begin{array}{l}\text { Heterophils } \\
(\mathrm{G} / \mathrm{l})\end{array}$ & $1.67^{\mathrm{a}} \pm 0.25$ & $7.93^{\mathrm{B}} \pm 0.60$ & $7.79^{\mathrm{B}} \pm 0.93$ \\
\hline $\begin{array}{l}\text { Lymphocytes } \\
(\mathrm{G} / \mathrm{l})\end{array}$ & $9.63^{\mathrm{a}} \pm 1.36$ & $9.68^{\mathrm{a}} \pm 0.95$ & $7.55^{\mathrm{a}} \pm 0.73$ \\
\hline $\begin{array}{l}\text { Eosinophils } \\
(\mathrm{G} / \mathrm{l})\end{array}$ & $0.07^{\mathrm{a}} \pm 0.01$ & $0.09^{\mathrm{a}} \pm 0.01$ & $0.09^{\mathrm{a}} \pm 0.01$ \\
\hline $\begin{array}{l}\text { Basophils } \\
(\mathrm{G} / \mathrm{l})\end{array}$ & $0.06^{\mathrm{a}} \pm 0.01$ & $0.11^{\mathrm{a}, \mathrm{c}} \pm 0.02$ & $0.14^{\mathrm{b}, \mathrm{c}} \pm 0.03$ \\
\hline $\begin{array}{l}\text { Monocytes } \\
(\mathrm{G} / \mathrm{l})\end{array}$ & $0.09^{\mathrm{a}} \pm 0.02$ & $0.15^{\mathrm{a}} \pm 0.04$ & $0.13^{\mathrm{a}} \pm 0.02$ \\
\hline H/L ratio & $0.17^{\mathrm{a}} \pm 0.02$ & $0.88^{\mathrm{B}} \pm 0.10$ & $1.05^{\mathrm{B}} \pm 0.09$ \\
\hline
\end{tabular}

$\mathrm{H} / \mathrm{L}$ ratio $=$ heterophil to lymphocyte ratio, $\mathrm{G} / 1=10^{9} / 1$

Means within a row lacking a common superscript differ. Identical letter size indicates $p<0.05$, different letter size indicates $p<0.01$.

It follows from the table that both 2 - and 5-min shackling periods induced highly significant increases in heterophil counts $(p<0.01)$ and subsequently the markedly elevated $(p<0.01)$ heterophil to lymphocyte ratio in shackled broilers in comparison with unshackled control. When S2 and S5 chickens were compared, the mean value of the H/L ratio was higher due to a longer shackling period. The difference, however, was not statistically significant. Nor were the differences in other monitored parameters. In addition, S5 broilers also exhibited a statistically significant $(p<0.05)$ increase in the number of basophils in comparison with the control group. 


\section{Discussion}

The results of our experiment indicate that shackling procedure is a considerably traumatic experience for the broiler chickens, and markedly contributes to the stress response in preslaughter handling. This statement is in agreement with Knowles and Broom (1990) who compared various preslaughter processes in broilers and concluded that the handling component was the most potent stressor for broiler chickens. The handling method adopted may have implications for the bird welfare. Similarly, Sparrey and Kettlewell (1994) mentioned that even if the practice of suspension for slaughter in poultry is necessary for present methods of humane slaughter, it causes possible distress and pain to the birds. Based on monitoring nociceptors in the legs of poultry in response to quantitative mechanical stimulation, Gentle and Tilst on (2000) also concluded that shackling is likely to be a very painful procedure.

According to our experimental results, stress effects connected with the shackling procedure induce strong changes in haematological indices of both leukocyte and erythrocyte counts in broilers. Nevertheless there are only small differences in the changes caused by the length of shackling period. In our experiment, we detected that both 2- and 5-min shackling periods induced a highly significant increase in heterophil counts and subsequently the heterophil to lymphocyte ratio, that is commonly used as an index of stress status in birds (e.g. Gross and Siegel 1983; Maxwell 1993; Zulkifli et al. 2000). The heterophil to lymphocyte ratio was increased from 0.17 to 0.88 due to a 2 -min shackling period. According to Siegel and Gross (2000), we can deduce that the shackling of broilers for a 2-min period is a very stressful procedure. These authors state that H/L ratios ranging between 0.6 and 1.2 indicate higher levels of stress. As a result of a 5-min shackling period, we observed further elevation in the $\mathrm{H} / \mathrm{L}$ ratio to 1.05 . When $\mathrm{S} 2$ and $\mathrm{S} 5$ chickens were compared, the mean value of $\mathrm{H} / \mathrm{L}$ ratio was higher due to a longer shackling period, the difference, however, was not statistically significant. The elevation of $\mathrm{H} / \mathrm{L}$ ratio due to exposure to a short-term physical stressor is described also by Gros s (1990).

In addition, we detected that extension of the shackling period to 5-minutes not only induced the elevation in $\mathrm{H} / \mathrm{L}$ ratio and heterophil counts, but also significantly increased number of basophils in blood of broilers in comparison with a control group. These results correspond with Jen sen et al. (2000) who state that basophil numbers can also be increased during stress causing an acute stress of life-threatening magnitude.

Alongside substantial changes in blood profiles, we often observed strong wing flapping responses in the early shackling period, indicated a considerable high level of stress impact in shackled broilers in our experiment. This vigorous struggling and wing flapping can compromise the broiler's welfare and subsequently seriously damage product quality (Jones et al. 1998a, b; Satterlee et al. 2000; Debut et al. 2003). Kannan et al. (1997), who also studied the welfare and meat quality effects of shackling, suggested a minimization of stress and meat quality changes in poultry by reducing the maximum time lapse between shackling and stunning or killing to 2 min.

Results from our experiment proved that the preslaughter shackling induced considerable changes in haematological indices of both leukocyte and erythrocyte count in broilers that indicate a markedly increased level of stress effects. Even after the elimination of other possible stress factors, significant changes after a 2-min shackling period were observed. This means that such a short delay between shackling and stunning in the slaughtering process is capable of inducing a considerable stress response in broiler chickens under commercial conditions. In conclusion, we agree with Raj and Tserveni-Gousi (2000), who recommend using a method eliminating the stress associated with the shackling of live birds before electrical stunning (e.g. stunning/killing of poultry still in their transport containers using gas mixtures) as the best future option as far as bird welfare is concerned. 


\section{Vliv stresu v důsledku zavěšení na hematologický profil brojlerových kuřat}

Cílem práce bylo stanovit vliv různé doby zavěšení na brojlery za podmínek simulujících praxi na jatkách. Jako ukazatel úrovně stresu byl hodnocen poměr heterofilů a lymfocytů (H/L). Stanoven byl také celkový počet erytrocytů a leukocytů, hematokrit, hemoglobin, střední objem erytrocytu (MCV), hemoglobinový obsah $(\mathrm{MCH})$, střední hemoglobinová koncentrace erytrocytu (MCHC) a diferenciální počet leukocytů. Ve věku 42 dnů bylo deset brojlerů zavěšeno po dobu 2 minut (skupina S2) a jiných deset brojlerů po dobu 5 minut (skupina S5). V průběhu pokusu bylo vyloučeno působení dalších faktorů (umístění do přepravních kontejnerů, přeprava, mikroklimatické vlivy atd.), kterým je v praxi drůbež před porážkou vystavena, aby bylo možné stanovit pouze reakci brojlerů na zavěšení. Zavěšení brojlerů vyvolalo u obou skupin (S2, S5) vysoce významné zvýšení počtu heterofilů a poměru H/L ve srovnání s kontrolní skupinou. Při srovnání skupin S2 a S5 byla průměrná hodnota poměru H/L u skupiny S5 vyšší, než u skupiny brojlerů zavěšených na kratší dobu, i když tento rozdíl nebyl statisticky významný. U skupiny S5 bylo dále zjištěno statisticky významné zvýšení počtu basofilů ve srovnání s kontrolní skupinou. U skupiny S2 došlo v důsledku zavěšení ke statisticky významnému snížení hladiny hemoglobinu, vysoce významnému snížení celkového počtu erytrocytů a hodnoty MCHC. U obou skupin byla dále zjištěna vysoce významně vyšší hodnota MCV a nižší hodnota celkového počtu erytrocytů a hodnoty MCHC ve srovnání s kontrolní skupinou. Mezi skupinami S2 a S5 nebyly zjištěny statisticky významné rozdíly $\mathrm{v}$ žádném ze sledovaných hematologických ukazatelů. Výsledky experimentu prokázaly, že zavěšení brojlerů před omráčením vyvolává výrazné změny v hematologickém profilu, které dokumentují výrazně zvýšenou hladinu stresu. Z hlediska welfare drůbeže je tedy žádoucí eliminovat stres spojený se zavěšením před omráčením.

\section{Acknowledgements}

This study was supported by the Ministry of Education, Youth and Sports of the Czech Republic (MSM Project No. 6215712402).

\section{References}

BUSCH RJ 2005: Ethical responsibility in livestock breeding. Zuchtungskunde 77: 420-425

COUNCIL DIRECTIVE 93/119/EC on the protection of animals at the time of slaughter or killing 1993: Official Journal L 340: 21 - 34

DEBUT M, BERRI C, BAEZA E, SELLIER N, ARNOULD C, GUEMENE D, JEHL N, BOUTTEN B, JEGO Y, BEAUMONT C, LE BIHAN-DUVAL E 2003: Variation of chicken technological meat quality in relation to genotype and preslaughter stress conditions. Poultry Sci 82: 1829-1838

DOUSEK J, VEČEREK V, VALCL O, CHLOUPEK P, PIŠTĚKOVÁ V 2002: Protection of animals against cruelty: Transport of cattle, sheep, goats and pigs. Acta Vet Brno 71: 555-562

FULPONI L 2006: Private voluntary standards in the food system: The perspective of major food retailers in OECD countries. Food Policy 31: 1-13

GENTLE MJ, TILSTON VL 2000: Nociceptors in the legs of poultry: Implications for potential pain in preslaughter shackling. Anim Welf 9: 227-236

GROSS WB 1990: Effect of exposure to a short duration sound on the stress response of chickens. Avian Dis 34: 759-761

GROSS WB, SIEGEL HS 1983: Evaluation of the heterophil lymphocyte ratio as a measure of stress in chickens. Avian Dis 27: 972-979

JENSEN P, BERG C, BESSEI W, FAURE JM, PORIN F, SAN GABRIEL CLOSAS A, SAVORY J, WHITEHEAD C 2000: The Welfare of Chickens Kept for Meat Production (Broilers), Report of the Scientific Committee on animal Health and animal Welfare of the EU, SANCO.B.3/AH/R15.

JONES RB, SATTERLEE DG 1997: Restricted visual input reduces struggling in shackled broiler chickens. Appl Anim Behav Sci $52: 109-117$

JONES RB, HAGEDORN TK, SATTERLEE DG 1998a: Adoption of immobility by shackled broiler chickens: effects of light intensity and diverse hooding devices. Appl Anim Behav Sci 55: 327-335

JONES RB, SATTERLEE DG, CADD GG 1998b: Struggling responses of broiler chickens shackled in groups on a moving line: effects of light intensity, hoods, and 'curtains'. Appl Anim Behav Sci 58: 341-352

KANNAN G, HEATH JL, WABECK CJ, MENCH JA 1997: Shackling of broilers: effects on stress responses and breast meat quality. Brit Poultry Sci 38: 323-332 
KNOWLES TG, BROOM DM 1990: The handling and transport of broilers and spent hens. Appl Anim Behav Sci 28: 75-91

MAXWELL MH 1993: Avian blood leukocyte responses to stress. World Poultry Sci J 49: 34-43

MENGERT U, FEHLHABER K 1996: Investigations of the influence of premortal stress on the endogenic microbial contamination in broiler carcasses. Berl Mun Tierarztl Wochenschr 109: 28-31

RAJ M, TSERVENI-GOUSI A 2000: Stunning methods for poultry. World Poultry Sci J 56: 291-304

SATTERLEE DG, PARKER LH, CASTILLE SA, CADD CG, JONES RB 2000: Struggling behavior in shackled male and female broiler chickens. Poultry Sci 79: 652-655

SIEGEL PB, GROSS WB 2000: General Principles of Stress and Well-being. In: GRANDIN T (Ed): Livestock Handling and Transport. Cabi Publishing, Wallingford, pp. 27-41.

SPARREY JM, KETTLEWELL PJ 1994: Shackling of poultry - is it a welfare problem. World Poultry Sci J 50: 167-176

VEČEREK V, MALENA M JR, MALENA M, VOSLÁŘOVÁ E, BEDÁŇOVÁ I 2006: Mortality in dairy cows transported to slaughter, from the standpoint of travel distance and seasonality. Acta Vet Brno 75: 449-454

VEČEREK V, PIŠTEKKOVÁ V, DOUSEK J, CHLOUPEK P 2002: The standard of protection of farm animals in a selected region of the Czech Republic. Acta Vet Brno 71: 263-268

VOSLÁŘOVÁ E, HANZÁLEK Z, VEČEREK V, STRAKOVÁ E, SUCHÝ P 2006: Comparison between laying hen performance in the cage system and the deep litter system on a diet free from animal protein. Acta Vet Brno 75: 219-225

ZULKIFLI I, CHE NORMA MT, CHONG CH, LOH TC 2000: Heterophil to lymphocyte ratio and tonic immobility reactions to preslaughter handling in broiler chickens treated with ascorbic acid. Poultry Sci 79: 402-406

ZULKIFLI I, GILBERT J, LIEW PK, GINSOS J 2002: The effects of regular visual contact with human beings on fear, stress, antibody and growth responses in broiler chickens. Appl Anim Behav Sci 79: 103-112 